\title{
AKUNTABILITAS DAN TRANSPARASI LEMBAGA AMIL ZAKAT (STUDI TERHADAP RUMAH PEDULI NURUL FIKRI KOTA PALANGKA RAYA) Mohamad Alfi
}

Fakultas Syariah IAIN Palangka Raya mohamadalfi@gmail.com

\section{ABSTRACT}

The Amil Zakat Institute, Rumah Peduli Nurul Fikri Palangka Raya, is one of the manifestations of the Law-based Zakat Management institution, established by the community as an effort to reduce poverty and facilitate the muzakki in channeling zakat. Rumah Peduli Nurul Fikri is a concrete form of an organization with a modern concept presented in the city of Palangka Raya by emphasizing the principles of accountability and transparency in collecting and distributing zakat, as in Article 17 of Law Number 23 of 2011 about Management of Zakat to realize the main purpose of zakat as an effort for the prosperity of muslims. The formulation of the problem in this study is how accountability in the management of the Rumah Peduli Nurul Fikri amil zakat institution in Palangka Raya and how transparency in the management of the Rumah Peduli Nurul Fikri amil zakat institution in Palangka Raya. This research uses descriptive qualitative approach with empirical sociological law research as long as the data obtained in observation, interviews, and documentation. The results of this study are the accountability of Rumah Peduli Nurul Fikri's amil zakat institution which is characterized by legal entities and also fulfills the principle of zakat management accountability, namely based on Islamic law, trust, benefits, justice, legal certainty, integrity, and responsibility. This is the fulfillment of legal compliance as Article 2 of Act Number 23 of 2011 concerning the Management of Zakat. Transparency of the Rumah Peduli Nurul Fikri amil zakat institution in Palangka Raya City is seen in managing zakat funds through disclosure of financial information and reporting to authorized institutions participating in the management of zakat. Transparency in the institution of Amil Zakat Rumah Peduli Nurul Fikri is open in managing zakat through the process of implementing activities and information that can be accessed by the public.

Keywords: Accountability, Transparancey, Zakat, Rumah Zakat.

\section{ABSTRAK}

Lembaga Amil Zakat, Rumah Peduli Nurul Fikri Palangka Raya, merupakan salah satu perwujudan lembaga berbasis Undang-Undang tentang Pengelolaan Zakat, didirikan oleh masyarakat sebagai upaya untuk mengurangi kemiskinan dan memfasilitasi para muzakki dalam menyalurkan zakat. Rumah Peduli Nurul Fikri adalah bentuk konkret dari sebuah organisasi dengan konsep modern yang disajikan di kota Palangka Raya dengan menekankan prinsip akuntabilitas dan transparansi dalam mengumpulkan dan mendistribusikan zakat, seperti dalam Pasal 17 Undang-Undang Nomor 23 tahun 2011 tentang Pengelolaan Zakat untuk mewujudkan tujuan utama zakat sebagai upaya untuk kemakmuran umat Islam. Rumusan masalah dalam penelitian ini adalah bagaimana akuntabilitas dalam pengelolaan lembaga amil zakat Rumah Peduli Nurul Fikri di Palangka Raya dan bagaimana transparansi dalam pengelolaan lembaga amil zakat Rumah Peduli Nurul Fikri di Palangka Raya. Penelitian ini menggunakan pendekatan kualitatif deskriptif dengan penelitian hukum sosiologis empiris selama data yang diperoleh dalam observasi, wawancara, dan dokumentasi. Hasil dari penelitian ini adalah akuntabilitas 
lembaga amil zakat Rumah Peduli Nurul Fikri yang dicirikan oleh badan hukum dan juga memenuhi prinsip akuntabilitas pengelolaan zakat, yaitu berdasarkan syariat Islam, kepercayaan, manfaat, keadilan, kepastian hukum, integritas, dan bertanggung jawab. Ini adalah pemenuhan kepatuhan hukum sebagaimana Pasal 2 Undang-undang Nomor 23 Tahun 2011 tentang Pengelolaan Zakat. Transparansi lembaga amil zakat Rumah Peduli Nurul Fikri Kota Palangka Raya terlihat dalam mengelola dana zakat melalui pengungkapan informasi dan pelaporan keuangan kepada lembaga-lembaga berwenang yang berpartisipasi dalam pengelolaan pengelolaan zakat. Transparansi di lembaga amil zakat Rumah Peduli Nurul Fikri terbuka dalam pengelolaan zakat melalui proses pelaksanaan kegiatan dan informasi yang dapat diakses oleh publik

Kata Kunci: Akuntabilitas, Transparansi, Zakat, Rumah Zakat.

\section{A. Pendahuluan}

Undang-Undang Republik Indonesia Nomor 38 tahun 1999 tentang pengelolaan zakat merupakan salah satu tonggak sejarah pengelolaan zakat Indonesia yang modern dengan melalui kelembagaan. Dengan adanya lembaga amil yang menghimpun zakat diharapkan akan berpengaruh terhadap pengurangan kemiskinan dan kesenjangan kesejahteraan di kalangan masyarakat, serta diperbaharui dengan Undang-Undang Nomor 23 Tahun 2011 tentang Pengelolaan Zakat. Dalam sejarah dakwah perubahan sosial masyarakat yang menjadi tema sentral yang dilancarkan oleh individu-individu yang menghasilkan tingkat sosial masyarakat yang ideal. Akan tetapi, proses merekayasa masyarakat tidak semudah membalik telapak tangan, namun ia harus menunggu proses yang panjang.

Saat ini perubahan masyarakat yang sangat dinanti-nantikan adalah upaya meningkatkan kemampuan ekonomi masyarakat Islam atau yang disebut dengan upaya memberdayakan ekonomi umat. Karena itu, bagi umat Islam diperlukan strategi yang didasarkan pada kebutuhan ekonomi masyarakat Islam, salah satunya dengan menyadarkan masyarakat muslim tentang potensi dan kekuatan ekonominya. Islam sangat menghargai dan melindungi hak milik seseorang akan tetapi pada saat yang sama, harta benda yang dimiliki tersebut merupakan hak umat manusia untuk dinikmati dan digunakan. ${ }^{1}$

Harta benda merupakan amanat yang harus dipelihara dan dikelola oleh pemiliknya untuk kemaslahatan manusia sesuai dalam batas-batas yang ditentukan oleh pencipta-Nya. Dengan kata lain dalam hak milik terdapat fungsi sosial dengan suatu kewajiban untuk memanfaatkan harta benda tersebut. Hal ini menunjukan bahwa dalam Islam terdapat dasar bagi perumusan-perumusan yuridis dalam menciptakan sistem kesejahteraan sosial. ${ }^{2}$

Islam memiliki persfektif tersendiri berkaitan dengan pertanggungjawaban karena dalam Islam semua yang dititipkan kepada manusia adalah amanah, konsep amanah merupakan bagian universal yang kemudian dituntunkan menjadi pertanggungjawaban (akuntabilitas), sebuah konsep barat yang diturunkan dari teori Agensi ${ }^{3}$. Pengelolaan zakat yang terakuntabilitasi atau amanah sebenarnya bukan konsep baru dalam Islam namun perlu dilembagakan yang meliputi

\footnotetext{
${ }^{1}$ Nahed Nurwairah, Permberdayaan Ekonomi Umat Melalui Wakaf, Sekolah Tinggi Agama Islam Palangka Raya: Jurnal Kajian Islam, volume 1 nomor 1, 2009, h. 52.

${ }^{2} I$ Ibid., h. 53.

${ }^{3}$ Teori agensi merupakan konsep yang menjelaskan hubungan kontraktual antara principalsdan agents. Pihak principalsadalah pihak yang memberikan mandat kepada pihak lain, yaitu agent, untuk melakukan semua kegiatan atas nam aprincipals dalam kapasitasnya sebagai pengambil keputusan.
} 
pertanggungjawaban kepada yang memberi amanah, Penerima amanah dan amanah itu sendiri. Pemberi amanah dalam hal ini adalah Allah SWT yang telah menciptakan manusia sebagai wakilnya di bumi (khalifatullah fill ardh) seperti dalam Alquran Surah Fathir ayat 39:

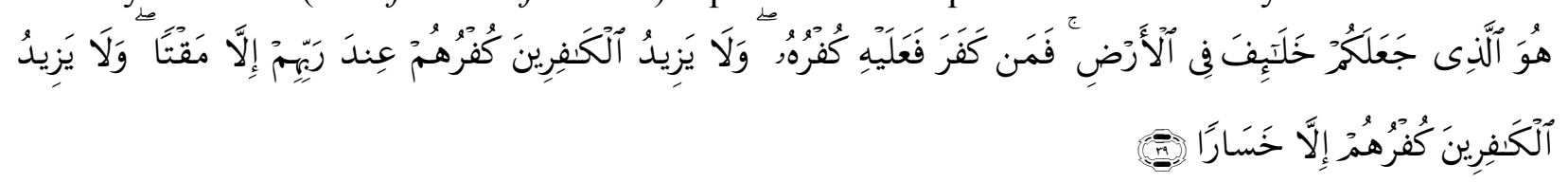

Artinya:

Dia-lah yang menjadikan kamu khalifah-khalifah di muka bumi. Barangsiapa yang kafir, maka (akibat) kekafirannya menimpa dirinya sendiri. Dan kekafiran orang-orang yang kafir itu tidak lain hanyalah akan menambah kemurkaan pada sisi Tuhannya dan kekafiran orang-orang yang kafir itu tidak lain hanyalah akan menambah kerugian mereka belaka. ${ }^{4}$ 'Dialah yang menjadikanmu khalifah-kahlifah di bumi', mempunyai makna si penerima amanah (khalifah) harus melakukan tugasnya di bumi secara bertanggung jawab, dan dalam menjalankan amanah tersebut harus bersifat adil dan menjadikannya sebagai rahmat (bermanfaat bagi orang lain).

Salah satu permasalahan yang kini tengah dihadapi masyarakat Indonesia termasuk kota Palangka Raya adalah kemiskinan. Menyikapi kondisi demikian, ajaran Islam yang dibangun atas lima dasar pilar yang termuat dalam rukun Islam salah satunya memuat tentang zakat. Zakat adalah Ibadah fardiyah yang mengukuhkan hubungan vertikal antara Muzakki (pembayar zakat) dengan Tuhannya yang merefleksikan nilai spiritualitas yang mampu menumbuhkan nilai charity (kedermawanan) terhadap sesama manusia bahkan memiliki implikasi luas dalam aspek kehidupan sosial (jama'iyah), ekonomi (iqtishadiyah), budaya (tsaqafah), pendidikan (tarbiyah) dan aspek-aspek lainnya. ${ }^{5}$

Alquran membicarakan zakat dan mengaitkannya dengan sholat hampir 82 ayat yang diantaranya dalam QS. Al-Baqarah ayat 43

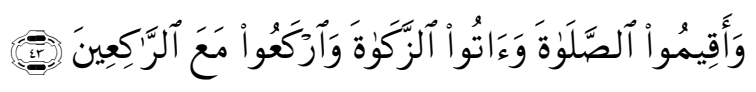

Artinya:

Dan dirikanlah sholat, tunaikanlah zakat dan ruku'lah beserta orang-orang yang ruku' ${ }^{6}$

Zakat jika ditinjau dari sistem ekonomi Islam merupakan salah satu instrumen fiskal untuk mencapai tujuan keadilan sosial-ekonomi dan distribusi kekayaan dan pendapatan sebagai salah satu intsrumen dalam pengentasan kemiskinan. Di Indonesia kegiatan perzakatan mulai berkembang pada tahun 1990-an dengan munculnya lembaga amil zakat yang pengelolaannya full time dan dilaksanakan secara profesional. Hal tersebut merupakan tonggak sejarah pengelolaan zakat di Indonesia, karena pada saat itu pula mulai muncul unsur-unsur profesional dan manajemen modern dalam pengelolaan zakat.

Berdasarkan observasi peneliti, Lembaga Amil Zakat Rumah Peduli Nurul Fikri merupakan salah satu realisasi dari Undang-Undang Pengelolaan Zakat yang berbasis lembaga yang didirikan oleh masyarakat kota Palangka Raya sebagai upaya pengentasan kemiskinan dan

\footnotetext{
${ }^{4}$ Departemen Agama RI, Al- Qur'an dan terjemahannya, Depok: Cahaya Qur'an, 2008, h.

${ }^{5}$ Muhammad dan Abubakar, Manajemen Organisasi Zakat, Malang: Madani (kelompok penerbit Instrans), 2011, h. 1.

${ }^{6}$ Departemen Agama RI, Al-Qur'an dan terjemahannya,..... h. 7.
} 
memfasilitasi para Muzakki dalam menyalurkan hartanya untuk berzakat. ${ }^{7}$ Rumah Peduli Nurul Fikri merupakan bentuk nyata sebuah amil dengan konsep modern yang hadir di kota Palangka Raya dengan mengedepankan asas akuntabilitas dan transparansi dalam mengumpulkan, menghimpun, dan mendistribusikan zakat kepada para mustahiq, sebagaimana di Pasal 17 Undang-Undang nomor 23 Tahun 2011 tentang Pengelolaan Zakat untuk mewujudkan tujuan utama zakat yaitu kesejahteraan umat Islam.

Inilah yang membuat penulis tertarik untuk mengkaji Rumah Peduli Nurul Fikri dalam menggalang, menghimpun dan mendistribusikan zakat sehingga antara mustahiq dan muzakki itu terjadi sikap check and balance yang tidak lain akan menghasilkan dana dari muzakki maksimal dan distribusi yang merata kepada mustahiq. Pembahasan ini penulis tuangkan dalam tulisan yang berjudul Akuntabilitas dan Transparansi Lembaga Amil Zakat (Studi Terhadap Rumah Peduli Nurul Fikri Kota Palangka Raya). Beranjak dari gambaran umum latar belakang di atas, ada beberapa pokok permasalahan yang akan dikaji dan diteliti dalam penelitian ini diantaranya: bagaimana akuntabilitas dalam pengelolaan lembaga amil zakat Rumah Peduli Nurul Fikri Kota Palangka Raya dan bagaimana Transparansi dalam pengelolaan Lembaga Amil Zakat Rumah Peduli Nurul Fikri Kota Palangka Raya

\section{B. Pembahasan}

\section{Akuntabilitas dalam Pengelolaan Lembaga Amil Zakat Rumah Peduli Nurul Fikri} Kota Palangka Raya

Lembaga Amil Zakat adalah lembaga yang melayani kepentingan publik dalam penghimpunan dan penyaluran dana umat. Sebagai organisasi sektor publik tentu saja Lembaga Amil Zakat memiliki stakeholder yang sangat luas. Konsekuensinya Lembaga Amil Zakat (LAZ) dituntut dapat memberikan informasi mengenai pengelolaan kepada semua pihak yang berkepentingan. Kemampuan untuk memberikan informasi yang terbuka, seimbang dan merata kepada stakeholder terutama mengenai pengelolaan keuangan adalah salah satu kreteria yang menentukan tingkat akuntabilitas dan aksesibilitas lembaga. Jika keterpercayaan publik kepada lembaga tetap terjaga, maka pada akhirnya masyarakat akan terus menyalurkan dananya lewat lembaga.

Berbicara mengenai ketidakpercayaan masyarakat terhadap organisasi sektor publik, lebih disebabkan oleh kesenjangan informasi antara pihak pengelola yang memiliki akses langsung terhadap informasi dengan pihak masyarakat yang berada diluar manajemen. Pada tataran ini, konsep mengenai akuntabilitas dan aksesibilitas menempati kriteria yang sangat penting terkait dengan pertanggungjawaban organisasi dalam menyajikan, melaporkan dan mengungkap segala aktifitas kegiatan serta sejauh mana laporan keuangan memuat semua informasi yang relevan yang dibutuhkan oleh para pengguna dan seberapa mudah informasi tersebut diakses oleh masyarakat.

Terkait pelaksanaan audit terhadap Lembaga Amil Zakat, Pasal 18 ayat (2) huruf $\mathrm{h}$ Undang-Undang Nomor 23 Tahun 2011 tentang Pengelolaan Zakat telah mengatur syarat pembentukan Lembaga Amil Zakat, salah satunya yaitu bersedia diaudit secara berkala dan pada Pasal 19 menyebutkan Lembaga Amil Zakat wajib melaporkan pelaksanaan pengumpulan,

\footnotetext{
${ }^{7}$ Administrator, 2015, http://www.rpnf.org/profil-rpnf/ Diakses pada tanggal 27 April 2015 Pukul 18.53 WIB
} 
pendistribusian, dan pendayagunaan zakat yang telah diaudit kepada Badan Amil Zakat Nasional (BAZNAS) secara berkala.

Berdasarkan hasil wawancara yang peneliti lakukan terhadap subjek I memberikan keterangan bahwa laporan ke pengawas atau stakeholder pertama kepada mitra jadi kategori kerjasama kemitraan yang bersifat kegiatan insidental atau orderan, wajib melaporkan langsung dalam satu buku laporan baik itu laporan keuangan atau laporan kegiatan selain memberikan ke mitra lembaga juga memberikan ke muzakki dalam bentuk laporan di website dan melalui media sosial (Whatapps). Sedangkan laporan lembaga amil zakat Rumah Nurul Fikri memberikan laporan ke lembaga pengawas yaitu Dinas Sosial, Dinas Pendapatan Daerah, Kantor Wilayah Kementerian Agama (KEMENAG) dan Badan Amil Zakat Nasional (BAZNAS) selain itu subjek II juga memberikan keterangan laporan lembaga amil zakat Rumah Peduli Nurul Fikri tidak hanya ke 4 (empat) stakeholder tapi juga memberikan laporan ke yayasan dengan waktu pelaporan 1 (satu) x 1 (Satu) semester atau bisa juga menyesuaikan kebutuhan stakeholder dan berdasarkan Surat Keterangan Terdaftar Nomor: 300.3.2/552/BKBP/XII/2015 di Badan Kesatuan Bangsa Dan Politik bahwa wajib menyampailan laporan akhir tahun ke Badan Kesatuan Bangsa dan Politik Kota Palangka Raya. Sesuai dengan keterangan yang didapat melalui wawancara dengan Informan YF, AA, SN bahwa lembaga amil zakat Rumah Peduli Nurul Fikri memang benar melaporkan kegiatan dan keuangan sebagai mana waktu yang telah ditentukan,

Selain itu subjek I dan subjek II juga menerangkan bahwa dasar hukum atau legalitas lembaga amil zakat Rumah Peduli Nurul Fikri Kedudukan secara Hukum Rumah Peduli Nurul Fikri sudah mendapatkan Akta Notaris No 1 tanggal 2 April 2007, oleh R.A. Setiyo Hidayat S.H dan diperbaiki dengan Akta Notaris No 35 tanggal 26 juli 2007, yang disahkan dengan keputusan Menteri Hukum dan Hak Asasi Manusia Republik Indonesia No. C-3033. HT. 01.02.TH 2007 serta ada perubahan Akta Notaris No. 71 tanggal 24 Maret 2016 selain Akta Notaris, di atas Rumah Peduli Nurul Fikri juga sudah mendapat Surat Keterangan terdaftar di Badan Kesatuan Bangsa Dan Politik Kota Palangka nomor: 00-11-00/07III/2016 dan juga mendapat Izin Penyelenggaraan Pengumpulan Uang dan Barang (PUB) nomor: 570/04/sosial/V/BPMDP-2016 dari Badan Penanaman Modal Daerah dan Perizinan Kota Palangka Raya.

Ditinjau dari sudut pandang teori akuntabilitas bahwa wujud akuntabilitas yang dapat dilakukan Badan Amil Zakat Infaq dan Sedekah antara lain Disclosures (pengungkapanpengungkapan) dalam bentuk publikasi pengelolaan sumber dan penggunaan dana. Adapun akuntabilitas lembaga mancakup hal sebagai berikut:

1. Menyediakan informasi yang bermanfaat dan relevan bagi pemerintah dan masyarakat luas untuk mengevaluasi tanggung jawab sosial organisasi, berdasarkan data yang peneliti temukan di lapangan dari keterangan diberikan subjek I, II, III IV, V, VI dan subjek VII dan dikuatkan dengan keterangan yang diberikan informan I, II dan III bahwa lembaga amil zakat Rumah Peduli Nurul Fikri sudah memenuhi syarat ini baik dengan pemerintah maupun kepada masyarakat yang membutuhkan informasi dengan adanya laporan seluruh kegiatannya dari laporan langsung kepada lembaga pengawas yakni BAZNAS sedangkan kepada masyarakat berupa laporan yang diunggah di website dan buletin yang disebarkan.

2. Menyediakan informasi mengenai pertukaran-pertukaran yang terjadi antar organisasi dan lingkungan sosial, berdasarkan laporan yang peneliti dapat bahwa di dalam laporan selain menerangkan jumlah dana tapi segala bentuk kegiatan lembaga amil zakat Rumah Peduli Nurul Fikri seperti hal seminar, bantuan kebakaran, bantuan banjir. 
3. Menyediakan informasi mengenai manfaat sosial (social benefit) dan biaya sosial (social cost) yang terjadi akibat operasi perusahaan atau nilai tambah yang diberikan oleh perusahaan (value add) untuk jangka waktu atau priode tertentu, dalam pelaksanaannya seluruh kegiatanya lembaga amil zakat Rumah Peduli Nurul Fikri berdasarkan kerterangan Subjek I bahwa kegiatan lembaga dirancang terlebih dahulu dan berapa target dana serta untuk apa saja dana yang dibutuhkan.

Oleh karena itu dari pemaparan diatas dan keterangan-keterangan yang diberikan subjek I, II, III IV, V, VI dan subjek VII dan dikuatkan dengan keterangan yang diberikan informan I,II dan III bahwa lembaga amil zakat Rumah Peduli Nurul Fikri sudah akuntabel serta dari observasi yang penulis lakukan dilapangan. Sedangkan ditinjau dari sudut pandang teori kepatuhan hukum teori ini jika dihubungkan dengan penelitian yang penulis teliti bahwa Lembaga Amil Zakat memang tidak dapat dipisahkan dari sebuah ketaatan hukum yang bersifat patuh, taat, tunduk pada ajaran dan peraturan.

Kepatuhan juga dapat diartikan sebagai suatu perubahan perilaku dari perilaku yang tidak menaati peraturan ke perilaku yang menaati peraturan guna untuk membangun suatu kepercayaan akan lembaga tersebut dalam visi misi yang menanamkan tanggungjawab atau akuntabilitas. Oleh sebab itu berdasarkan dokumen yang peneliti dapatkan seperti Akta Notaris No 1 tanggal 2 April 2007, oleh R.A. Setiyo Hidayat S.H yang diperbaikan dengan Akta Notaris No 35 tanggal 26 juli 2007 yang disahkan dengan keputusan Menteri Hukum dan Hak Asasi Manusia Republik Indonesia No. C-3033. HT. 01.02.TH 2007 dan perubahan Akta Notaris No. 71 tanggal 24 Maret 2016 selain Akta Notaris, di atas Rumah Peduli Nurul Fikri juga sudah mendapat Surat Keterangan Terdaftar di Badan Kesatuan Bangsa Dan Politik Kota Palangka nomor: 00-11-00/07III/2016 dan juga mendapat Izin Penyelenggaraan Pengumpulan Uang dan Barang (PUB) nomor: 570/04/sosial/V/BPMDP-2016 dari Badan Penanaman Modal Daerah dan Perizinan Kota Palangka Raya. Selain itu dalam UU No. 23 Tahun 2011 tentang Pengelolaan Zakat pasal 19, bahwa kepatuhan hukum Lembaga Amil Zakat juga meliputi wajib melapor kepada BAZNAS.

Berdasarkan analisis penulis di atas, norma yang terkait dengan akuntabilitas pengelolaan zakat mencakup kepatuhan terhadap prinsip-prinsip syariah, kepatuhan terhadap perundangundangan yang berlaku dalam negara, transparansi pengelolaan zakat, serta pertanggungjawaban secara berjenjang dalam pengelolaan zakat, hal inilah yang menjadi dasar akuntabilitas pengelolaan zakat pada lembaga amil zakat Rumah Peduli Nurul Fikri. Terkait dengan subyek pelaksanaan asas akuntabilitas, serta pengelola zakat pada lembaga amil zakat Rumah Peduli Nurul Fikri yang berbadan hukum sebagaimana dikuatkan oleh akta notaris dan juga legalitasnya dari Kementerian Hukum dan HAM, yakni lembaga amil zakat Rumah Peduli Nurul Fikri sebagai lembaga amil zakat perseorangan dan perkumpulan orang dalam masyarakat dari bentuk badan hukum yayasan kemudian dibentuk lembaga amil zakat dibawah kepengurusan yayasan Nurul Fikri. Lebih lanjut menurut penulis, pada lembaga amil zakat Rumah Peduli Nurul Fikri memiliki tujuan yang sama dengan asas akuntabilitas pengelolaan zakat yaitu tercapainya pelaksanaan asas akuntabilitas adalah sejalan dengan tujuan pengelolaan zakat dalam undangundang, yaitu meningkatnya efektivitas dan efisiensi pelayanan dalam pengelolaan zakat, dan meningkatnya manfaat zakat untuk mewujudkan kesejahteraan masyarakat dan penanggulangan kemiskinan.

Penegakan hukum berupa sanksi administratif diterapkan dalam kondisi ketika pengelola zakat tidak memberikan bukti setoran zakat, atau pendistribusian dan pendayagunaan dana 
zakat, infak, sedekah dan dana sosial keagamaan lainnya tidak sesuai ketentuan syariah, atau tidak melakukan pencatatan tersendiri atas penerimaan dana non zakat, atau tidak memberitahukan pengelolaan zakat yang dilakukan kepada pejabat yang berwenang (khusus amil zakat perorangan dan perkumpulan). Sedangkan sanksi pidana adalah terkait dengan tindakan melawan hukum yang tercantum dalam pasal-pasal larangan pada Undang-Undang Pengelolaan Zakat, yaitu larangan melakukan tindakan memiliki, menjaminkan, menghibahkan, menjual, mengalihkan zakat, infak, sedekah, atau dana sosial keagamaan lainnya yang ada dalam pengelolaannya.

Lebih lanjut berdasarkan kepatuhan hukum, pengelolaan zakat melalui lembaga amil zakat Rumah Peduli Nurul Fikri dalam konteks negara hukum, pengelolaan zakat diatur ke dalam wilayah privat kewarganegaraan dalam sektor keagamaan. Adapun pola pengawasan di dalam masyarakat terhadap pengelolaan zakat sebenarnya sudah ada dan sudah berjalan selama ini, yaitu dalam bentuk yang sangat sederhana melalui peran ulama dan kiyai di tingkat lokal. Tetapi setelah diberlakukannya Undang-Undang Pengelolaan Zakat, amil zakat diharuskan menerapkan aturan teknis administratif terhadap pelaksanaan ibadah ini. Pada prinsipnya tidak ada masalah jika negara harus masuk dalam pengawasan zakat, yakni untuk mencegah terjadinya pola-pola pengelolaan yang melawan hukum atau penyalahgunaan pengelolaan zakat.

Berdasarkan uraian di atas lebih lanjut menurut penulis, lembaga amil zakat Rumah Peduli Nurul Fikri menggunakan pola yang aman dalam pengelola zakat yang akuntabel adalah lembaga amil zakat yang berbadan hukum, ialah meminimalkan risiko hukum pengelolaan dana zakat kepada BAZNAS, yaitu pengumpulan, rekap dan serahkan ke BAZNAS Provinsi Kalimantan Tengah. Menurut penulis lembaga amil zakat Rumah Peduli Nurul Fikri harus menyeleksi siapa yang wajib menunaikan zakat dan siapa yang berhak menerima zakat. Orang yang berzakat jangan merasa terzalimi, misalnya pegawai yang gajinya pas-pasan jangan diambil zakatnya. Jangan mengambil sesuatu yang tidak wajib. Untuk itu seorang amil harus memiliki kompetensi dasar sebagai amil zakat, yaitu; ilmu syariah, fiqih zakat, integritas diri, kuat kepribadian, kelembutan, dan adil. ${ }^{8}$

Akuntabilitas hukum dan kejujuran (accuntability for probity and legality) terkait dengan dilakukannya kepatuhan terhadap hukum dan peraturan lain yang disyaratkan dalam organisasi, sedangkan akuntabilitas kejujuran terkait dengan penghindaran penyalahgunaan jabatan, korupsi dan kolusi. Akuntabilitas hukum menjamin ditegakkannya supremasi hukum, sedangkan akuntabilitas kejujuran menjamin adanya praktik organisasi yang sehat. Akuntabilitas manajerial yang dapat juga diartikan sebagai akuntabilitas kinerja (performance accountability) adalah pertanggungjawaban untuk melakukan pengelolaan organisasi secara efektif dan efisien. Akuntabilitas program juga berarti bahwa program-program organisasi hendaknya merupakan program yang bermutu dan mendukung strategi dalam pencapaian visi, misi dan tujuan organisasi.

Berdasarkan hasil analisis penulis, lembaga amil zakat Rumah Peduli Nurul Fikri mampu mempertanggungjawabkan program yang telah dibuat sampai pada pelaksanaan program. Akuntabilitas lembaga amil zakat Rumah Peduli Nurul Fikri mampu mempertanggungjawabkan kebijakan yang telah ditetapkan dengan mempertimbangkan dampak dimasa depan. Dalam membuat kebijakan harus dipertimbangkan apa tujuan kebijakan tersebut, mengapa kebijakan itu

\footnotetext{
${ }^{8} \mathrm{http}$ ://pusat.baznas.go.id/berita-artikel/akuntabilitas-pengelolaan-zakat-dalam-perspektif-hukum-islam-dan-
} keuangan/ 
dilakukan. Akuntabilitas merupakan pertanggungjawaban lembaga publik untuk menggunakan dana publik (public money) secara ekonomis, efisien dan efektif, tidak ada pemborosan dan kebocoran dana, serta korupsi. Akuntabilitas sangat penting karena menjadi sorotan utama masyarakat. Akuntabilitas ini mengharuskan lembaga-lembaga publik untuk membuat laporan keuangan untuk menggambarkan kinerja finansial organisasi kepada pihak luar. ${ }^{9}$

Berdasarkan analisi penulis di atas, akuntabilitas lembaga amil zakat Rumah Peduli Nurul Fikri sebagai lembaga amil pengelola zakat sudah akuntabel dengan berbadan hukum dan juga memenuhi prinsip akuntabilitas pengelolaan zakat, yaitu berdasarkan syariat Islam, amanah, kemanfaatan, keadilan, kepastian hukum, terintegritas, dan akuntabilitas. Hal ini merupakan pemenuhan kepatuhan hukum sebagaimana Pasal 2 Undang-Undang Nomor 23 Tahun 2011 Tentang Pengelolaan Zakat

2. Transparansi dalam Pengelolaan Lembaga Amil Zakat Rumah Peduli Nurul Fikri Kota Palangka Raya

Aspek penting dari pengelolaan zakat adalah peran para lembaga amil zakat selaku pengemban amanah pengelolaan dana-dana itu. Jika amil zakat baik, maka asnaf mustahik lainnya insya Allah akan menjadi baik, tapi jika amil zakatnya tidak baik, maka jangan diharap para asnaf mustahik yang lain akan menjadi baik. Itulah nilai strategisnya amil zakat, dengan kata lain, hal terpenting dari zakat adalah bagaimana mengelolanya.

Secara sosiologis, harapan publik adalah suskesnya pengelolaan zakat yang efektif dan efisien, tetapi seperti segala hal yang merupakan dambaan manusia biasanya memiliki wujud yang abstrak atau tidak jelas. Mengenai hal ini salah satu hal yang ingin diintegrasikan dalam proses perancangan adalah bagaimana membuat sistem ini menjadi transparan sesuai dengan prinsip Good Governance. Tetapi ketika dicoba untuk dicari user requirementnya (daftar kebutuhan pengguna) sebagai basis validasi perancangan timbul kesulitan bagaimana mendefinisikannya.

Selalu tetap ada batasan tentang apa yang bisa diketahui publik dan sebaiknya tidak diketahui publik. Dalam Lembaga Amil Zakat (LAZ) yang dituntut untuk meningkatkan kepercayaan bagi para Muzakki, tentunya tidak akan menguraikan rencana strategi kompetitifnya. Seharusnya ada lembaga publik atau otoritas yang ditunjuk dan berani untuk membuat sebuah kriteria yang jelas.

Dengan transparannya pengelolaan zakat, maka dapat menciptakan suatu sistem kontrol yang baik, karena tidak hanya melibatkan pihak intern organisasi saja tetapi juga akan melibatkan pihak ekstern seperti para Muzakki maupun masyarakat secara luas. Dan dengan transparansi inilah rasa curiga dan ketidak percayaan masyarakat akan dapat diminimalisasi.

Lembaga Amil Zakat Rumah Peduli Nurul Fikri dalam bentuk transparansinya mempunyai 3 (tiga) kriteria di antaranya :

1. Semua program yang dijalankan akan dilaporkan kepada semua stake holder (Muzakki, Dewan Pengawas dan Lembaga Mitra) secara berkala.

2. Lembaga mitra ataupun donatur perseorangan akan difasilitasi untuk bisa mengakses laporan dan laporan program.

3. Laporan akan dibuat secara transparan dengan melibatkan auditor, update akses yang mudah dan online. 
Dari pengertian transparansi yang dikemukakan di atas dapat ditarik suatu kesimpulan pengertian bahwa, prinsip transparasi itu sesungguhnya dibangun atas informasi yang bebas. Bebas maksudanya adalah bebas diakses oleh siapa saja yang membutuhkan, dan pemerintah berkewajiban untuk membeberkan informasi tersebut, terutama yang berkaitan dengan segala sesuatu yang diputuskan untuk dilakukan dan tidak dilakukan untuk urusan publik. Kendati demikian, perlu diketengahkan bahwa, lembaga yang transparan tidak saja berarti adanya keterbukaan informasi dan akses masyarakat karena boleh jadi ada informasi yang asimetris, tetapi penekanannya lebih pada makna "tanggung jawab". Tanggung jawab untuk memberikan informasi yang benar dan relevan kepada yang siapa saja yang membutuhkan atau kepada publik.

Dengan pemahaman demikian maka, sesungguhnya transparansi merupakan bentuk akuntabilitas yang sangat rasional untuk menghadapi sistem ekonomi dan administrasi. ${ }^{10}$

Berawal dari konsep transparansi yang peneliti paparkan jika dihubungkan dengan yang peneliti temukan dari hasil observasi dan wawancara dari subjek I, II, III, IV, V, VI dan VII yang memberikan keterangan sistem organisasi atau sistem kelembagaan yang terkait dengan struktur oraganisasi. Lembaga Amil Zakat Rumah Peduli Nurul Fikri untuk memenuhi kebutuhan penting dengan pengelolaan zakat maka beberapa unsur seperti kepemimpinan, menghimpun dana, penyaluran dan pendayagunaan, pengelolaan administrasi keuangan dan asset, pengelolaan SDM Amil yang mana unsur-unsur tersebut dibentuk dalam upaya pengelolaan zakat yang tertata dan terbuka.

Sistem keuangan Lembaga Amil Zakat Rumah Peduli Nurul Fikri mengunakan sistem akuntansi zakat online yang mana akuntansinya sudah berdasarkan PSAK 109 dan PSAK 110. Dari sisi sistem perencanaan yang dilakukan Rumah Peduli Nurul Fikri adanya rapat kerja, dengan agenda menyusun rencana kegiatan 1 (satu) tahun kedepan kemudian menetapkan target penghimpunan dan penetapan target penyaluran dan lain-lain terkait pengembangan.Sistem perencanaan yang diringi dengan sistem monev (monitoring dan evaluasi). Sedangkan laporan keuangan secara public dilakukan perbulan di website, dan juga laporan kegiatan dilaporkan paling lambat 24 jam setelah kegiatan itu dilaksanakan. Selain itu melalui media website lembaga amil zakat Rumah Peduli Nurul Fikri menebitkan buletin pertahun yang terbitnya di antara sesudah atau sebelum Ramadhan.

Menurut Undang-Undang No 23 Tahun 2011 Pasal 34, pembinaan dan pengawasan lembaga amil zakat dilaksanakan oleh Menteri Agama, Gubernur, dan Bupati/Walikota sesuai dengan kewenangannya. Adapun dalam hal pembinaan, menurut undang-undang meliputi sosialisasi, fasilitasi dan edukasi. Sedangkan pengawasan dalam Peraturan Pemerintah No. 14 Tahun 2014 tentang Pelaksanaan Undang-Undang Pengelolaan Zakat, mencakup pelaporan, audit syariah dan audit keuangan. Peraturan Pemerintah No 14 Tahun 2014 Pasal 75, menetapkan kewenangan Kementerian Agama untuk melakukan audit syariah atas laporan pelaksanaan pengelolaan zakat, infak, sedekah dan dana sosial keagamaan lainnya yang dilakukan oleh Badan Amil Zakat Nasional (BAZNAS) dan Lembaga Amil Zakat (LAZ). Melalui audit syariah dapat diketahui dan dipastikan pengelolaan zakat, infak, sedekah dan dana sosial keagamaan lainnya yang dilakukan badan amil zakat dan lembaga amil zakat telah

\footnotetext{
${ }^{10}$ Lucio Borromeo de Araujo, Penerapan prinsip transparansi, akuntabilitas dan prtisipasi masyarakat dalam local development program di timor-leste,....
} 
memenuhi prinsip-prinsip syariah Islam, serta untuk mencegah penyimpangan dan pelanggaran yang dilakukan oleh amil zakat.

Keberadaan Dewan Pengawas Syariah Lembaga Amil Zakat Rumah Peduli Nurul Fikri sangat diperlukan selain untuk memberikan kontrol syariah dan pendidikan, Dewan Pengawas Syariah dalam struktur Lembaga Amil Zakat akan meningkatkan kepercayaan terhadap Lembaga Amil Zakat Rumah Peduli Nurul Fikri apabila Dewan Pengawas Syariah melaksanakan tugasnya sesuai dengan fungsinya. Dengan begitu akan memberikan jaminan atas pengelolaan dana zakat sesuai dengan hukum-hukum zakat dan memberikan keyakinan bahwa personil lembaga amil zakat layak sebagai amil zakat selain itu hasil peneliti temukan dari wawancara dengan subjek II bahwa Dewan Syariah Lembaga Amil Zakat Rumah Peduli Nurul berfungsi mengawasi dan untuk mananyakan atau rujukan-rujukan syariah, adanya dewan syariah mengenai hal yang berkaitan dengan tugas lembaga yang dapat mendorong lembaga amil zakat untuk menciptakan "good corporate governance." Hal ini akan bermanfaat karena dengan tingginya kepercayaan masyarakat terhadap lembaga amil zakat, akan mendorong Muzakki menyalurkan zakatnya melalui lembaga amil zakat, dan tidak lagi disalurkan secara individu masing-masing Muzakki.

Pengawasan terhadap lembaga amil zakat sesungguhnya terkait erat dengan program yang direncanakan lembaga amil zakat tersebut, karena itu inti dari tujuan pengawasan adalah menjamin tercapainya tujuan lembaga amil zakat dengan cara mengembalikan atau meluruskan berbagai penyimpangan yang tidak sesuai dengan yang diprogramkan sehingga zakat benarbenar bisa diberdayakan untuk mengentaskan masalah perekonomian yang ada saat ini. Kepercayaan tersebut harus dibangun melalui akuntabilitas publik melalui pertanggungjawaban keuangan terutama operasional syariah lembaga amil zakat. Tujuan pengawasan haruslah positif, yaitu untuk memperbaiki, mengurangi pemborosan uang, waktu, material dan tenaga. Di samping itu, pengawasan juga bertujuan untuk membantu menegakkan agar peraturan ditaati, sehingga dapat mencapai efisiensi yang setinggi-tingginya.

Berdasarkan pemaparan diatas peneliti menyimpulkan bahwa Lembaga Amil Zakat Rumah Peduli Nurul Fikri memilik 3 (tiga) bentuk keterbukaan di antaranya keterbukaan dengan donatur berupa laporan langsung kepada donatur dan untuk masyarakat melalui buletin yang terbit sekali setahun serta website yang bisa diakses oleh masyarakat secara bebas dan kepada Muzakki laporan yang dilakukan selain melalui website juga dilakukan melalui media sosial (Whatapps dan SMS) berdasarkan konsep itu dan kenyataan yang ada bahwa lembaga cukup terbuka dengan segala bentuk kegiatan dan keuangan.

Menurut tinjauan teori transparansi bahwa suatu lembaga yang terbuka mencangkup 3 (tiga) aspek yaitu:

a. Semua program yang dijalankan akan dilaporkan kepada semua stakeholder (Muzakki, Dewan Pengawas dan Lembaga Mitra) secara berkala. Dari hasil peneliti didapatkan dari para subjek penelitian yang memberikan keterangan bahwa Lembaga Amil Zakat Rumah Peduli Nurul Fikri secara publik perbulan di website terkait laporan keuangan, kemudian ada laporan kegiatan per 24 (dua puluh empat) jam setelah kegiatan itu dilaksanakan. Pengawasan terhadap Lembaga Amil Zakat Rumah Peduli Nurul Fikri sesungguhnya terkait erat dengan program yang direncanakan lembaga amil zakat tersebut, karena itu inti dari tujuan pengawasan adalah menjamin tercapainya tujuan lembaga amil zakat dengan cara mengembalikan atau meluruskan berbagai penyimpangan yang tidak sesuai dengan yang diprogramkan sehingga zakat benar- benar bisa diberdayakan untuk mengentaskan masalah perekonomian yang ada saat ini. Kepercayaan tersebut harus dibangun melalui akuntabilitas 
publik melalui pertanggungjawaban keuangan terutama operasional syariah lembaga amil zakat. Tujuan pengawasan haruslah positif, yaitu untuk memperbaiki, mengurangi pemborosan uang, waktu, material dan tenaga. Di samping itu, pengawasan juga bertujuan untuk membantu menegakkan agar peraturan ditaati, sehingga dapat mencapai efisiensi yang setinggi-tingginya.

b. Lembaga mitra ataupun donatur perseorangan akan difasilitasi untuk bisa mengakses laporan dan laporan program. Dari hasil yang peneliti dapatkan dari para subjek penelitian yang memberikan keterangan bahwa Lembaga Amil Zakat Rumah Peduli Nurul Fikri secara laporan fisik yang diterbitkan persemester yang menerima laporan ini hanya donator.

c. Laporan akan dibuat secara transparan dengan melibatkan auditor, update, akses yang mudah dan online. Nurul fikri juga mempunyai laporan melalui media buletin diterbitkan pertahun di antara sesudah atau sebelum Ramadhan.

Transparansi yang dimiliki Lembaga Amil Zakat Rumah Peduli Nurul yang berupa akses mudah dengan prinsip online atau website yang di dalamnya memuat berbagai macam kategori atau menu pilihan diantaranya:

a. Home, yang memuat informasi aktivitas kegiatan dalam pelaksanaan program kerja yang mana ini merupakan laporan kegiatan Lembaga Amil Zakat Nurul Fikri.

b. Profil Kami, yang memuat hal-hal berupa keterangan Lembaga Amil Zakat Rumah Peduli Nurul seperti latar belakang berdirinya Lembaga Amil Zakat Rumah Peduli Nurul, Visi Misi, Tujuan, Konsep Operasional, Kategori Program, Struktur Organisasi, dan pengalaman Kerjasama.

c. Layanan, yang menyediakan sepertilayanan konsultasi zakat dan layanan jemput zakat dari seluruh kabupaten yang terdapat kantor cabang Lembaga Amil Zakat Rumah Peduli Nurul.

d. Program, kegiatan yang menjadi dasar Lembaga Amil Zakat Rumah Peduli Nurul Fikri untuk menyalurkan dana-dana yang diperoleh, dan penjelasan dari program yang terdapat di Lembaga Amil Zakat Rumah Peduli Nurul seperti : Disaster Risk Management (bidang pencegahan bencana), Program Umat Mandiri Nurul Fikri (Pum-NF), Program NF Relationship atau program khusus kemitraan dalam hal pengelolaan dana Corporate Social Responbility (CSR), Program Cahaya Generasi, Dan Program Charity \& Empowering.

e. Partnership, yang isi dari menu ini berupa laporan kegiatan kerja sama dengan mitra, seperti laporan penyaluran dan laporan menerima bantuan dari mitra.

f. Komunitas, menerangkan kegiatan yang berupa perkumpulan dalam kegiatan seperti pengajian bulanan dan forum silaturahim.

g. Laporan, di dalam laporan ini memuat laporan keuangan dari tahun 2013 sampai 2015 dan ditahun 2016 terkahir laporanya sampai di bulan September.

h. Donasi, memuat cara untuk mendonasikan harta para Muzakki baik itu berupa zakat penghasilan, infak dan shadaqah.

i. Konfirmasi, yang berupa biodata yang memberi donasi dan konfirmasi dana yang didonasikan digunakan untuk apa.

Berdasarkan uraian di atas, menurut penulis, transparansi lembaga amil zakat Rumah Peduli Nurul Fikri sebagai lembaga amil zakat mengacu pada prinsip shidiq, yaitu terbuka dan tidak menyembunyikan anggaran sebaliknya adalah bentuk kebohongan yang paling jelas. Dalam kaidah ushul figh ditegaskan bahwa ma la yatimmul wajib illa bih fahuwa wajib, kalau kewajiban tidak bisa dijalankan kecuali dengan sesuatu maka sesuatu itu menjadi wajib. Shidiq adalah kewajiban. Dalam pengelolaan anggaran kejujuran ini tidak bisa dijalankan kecuali 
dengan transparansi anggaran. Berdasarkan kaidah itu, maka menjalankan transparansi anggaran adalah wajib. Ini berarti, dalam pandangan Islam, menghindari transparansi anggaran adalah kemaksiatan yang dapat menghapuskan semua pahala ibadah kepada Allah SWT, sebab shidiq berkaitan dengan prinsip amanat sebagaimana terdapat dalam Pasal 2 Undang-Undang Nomor 23 Tahun 2011 tentang Pengelolaan Zakat, yaitu berdasarkan syariat Islam, amanah, kemanfaatan, keadilan, kepastian hukum, terintegritas, dan akuntabilitas.

Lebih lanjut berdasarkan hasil penelitan penulis, berkaitan dengan proses informasi anggaran, amanat berkaitan dengan kesetiaan untuk mengalokasikan dan mendistribusikan anggaran kepada yang berhak dalam istilah Islam, menyampaikan amanat kepada ahlinya sebagaimana pada lembaga amil zakat Rumah Peduli Nurul Fikri sebagai lembaga amil zakat untuk mengontrol shidiq dan amanat, diperlukan sistem pengawasan. Dengan menggunakan istilah para ahli ushul fiqh, dapat disimpulkan bahwa pengawasan wajib karena shidiq dan amanat tidak akan berjalan tanpanya. Pengawasan tidak dapat dilakukan dengan baik tanpa transparansi anggaran. Amanah menegakkan transparansi anggaran adalah kewajiban agama yang mulia. Hal tersebut bukan saja mengantarkan manusia pada berbagai kebajikan, tetapi juga mengantarkan mereka kepada surga yang dijanjikan. Secara duniawi, transparansi anggaran, dalam kata-kata imam Ali adalah upaya memerangi musuh negara, menyejahterakan penduduk, dan memakmurkan negeri. ${ }^{11}$

Jadi berdasarkan analisis penulis di atas, transparansi lembaga amil zakat Rumah Peduli Nurul Fikri sebagai lembaga amil zakat dalam pengelolaan zakat yang akuntabel, terlihat dengan keterbukaannya dalam mengelola dana zakat melalui keterbukaan informasi dan pelaporan keuangan kepada instansi berwenang yang ikut serta dalam intergrasi pengelolaan zakat. Hal ini menjadi dasar bahwa transparansi pada lembaga amil zakat Rumah Peduli Nurul Fikri bersifat terbuka dalam pengelolaan zakat melalui penyertaan semua unsur dalam pengambilan keputusan dan proses pelaksanaan kegiatan dengan transparannya pengelolaan zakat pada lembaga amil zakat Rumah Peduli Nurul Fikri dengan adanya kontrol dari pengurus internal dan pengawasan eksternal serta kontrol sosial dari masyarakat.

\section{Penutup}

Berdasarkan hasil penelitian yang dilakukan penulis tentang Akuntabilitas dan Transparansi Lembaga Amil Zakat (Studi terhadap Rumah Peduli Nurul Fikri Kota Palangka Raya), maka peneliti dapat mengambil kesimpulan akuntabilitas dalam pengelolaan lembaga amil zakat Rumah Peduli Nurul Fikri Kota Palangka Raya yang dilihat dari; Pertama, menyediakan informasi yang bermanfaat dan relevan bagi pemerintah dan masyarakat luas untuk mengevaluasi tanggung jawab sosial organisasi, bahwa lembaga amil zakat Rumah Peduli Nurul Fikri sudah memenuhi syarat ini baik dengan pemerintah maupun kepada masyarakat yang membutuhkan informasi dengan adanya laporan seluruh kegiatannya dari laporan langsung kepada lembaga pengawas yakni BAZNAS sedangkan kepada masyarakat berupa laporan yang diunggah di website dan buletin yang disebarkan. Kedua, menyediakan informasi mengenai pertukaran-pertukaran yang terjadi antar organisasi dan lingkungan sosial, berdasarkan laporan yang peneliti dapat bahwa di dalam laporan selain menerangkan jumlah dana tapi segala bentuk kegiatan lembaga amil zakat Rumah Peduli Nurul Fikri seperti hal seminar, bantuan kebakaran,

\footnotetext{
${ }^{11}$ Transparansi dalam Perspektif Islam, http://www.antikorupsi.org/id/content/transparansi-dalam-perspektif-islam,
} 
bantuan banjir. Ketiga, menyediakan informasi mengenai manfaat sosial (social benefit) dan biaya sosial (social cost) yang terjadi akibat operasi perusahaan atau nilai tambah yang diberikan oleh perusahaan (value add) untuk jangka waktu atau periode tertentu, dalam pelaksanaannya seluruh kegiatanya lembaga amil zakat Rumah Peduli Nurul Fikri. Di mana kegiatan lembaga dirancang terlebih dahulu dan berapa target dana serta untuk apa saja dana yang dibutuhkan.

Lembaga yang dikatakan akuntabel selain mencakup beberapa dasar diatas lembaga amil zakat harus memenuhi kepatuhan hukum yang berupa izin untuk mengumpulkan dana ummat serta adanya bentuk pengawasan. Lembaga amil zakat Rumah Peduli Nurul Fikri dari hasil penelitian penulis dapatkan bahwa lembaga amil zakat Rumah Peduli Nurul Fikri dengan Rekomendasi BAZNAS Nomor : 093/SET.BAZNAS/01.02/X/2017 dan izin dari Badan Kesatuan Bangsa Dan Politik kota Palangka Raya No. 00-11-00/07/III/2016 serta dari Badan Penanaman Modal Daerah dan Perizinan Kota Palangka Raya dalam penyelenggaraan mengumpulkan uang dan barang. Selain itu dalam pengawasan ada 4 (empat) lembaga pengawas yaitu Baznaz, Kemenag, Dinas Pendapatan Daerah dan Dinas Sosial sebagai mana yang termaktub dalan UU No. 23 tahun 2011 pasal (29) ayat 3. Jadi dapat disimpulkan bahwa Rumah Peduli Nurul Fikri amanah atau akuntabel.

Transparansi dalam pengelolaan lembaga amil zakat dalam konteks penyelenggaraannya berdasarkan terbuka, mudah dan dapat diakses oleh semua pihak yang membutuhkan serta disediakan secara memadai dan mudah dimengerti. Oleh kerena itu berdasarkan penelitian yang penulis dapatkan bahwa Rumah Peduli Nurul Fikri Kota Palangka Raya dilihat dari pengelolaannya yang berupa penertbitan buletin setelah ramadhan yang memuat segala bentuk kegiatan serta dilihat dari pelaporan yang bersifat publik yang ada di website yang memuat dari hal laporan dan kegiatan, serta adanya kerterbukaan dengan mitra dan Muzakki dalam kegiatan dana yang didapat yang di muat dalam grup media sosial seperti Whatsapp. Prinsip transparansi tersebut terlihat melalui keterbukaan informasi dan pelaporan keuangan kepada instansi berwenang yang ikut serta dalam intergrasi pengelolaan zakat. Hal ini menjadi dasar bahwa lembaga amil zakat Rumah Peduli Nurul Fikri bersifat terbuka dalam pengelolaan zakat melalui penyertaan semua unsur dalam pengambilan keputusan dan proses pelaksanaan kegiatan dengan transparannya pengelolaan zakat pada lembaga amil zakat Rumah Peduli Nurul Fikri.

Adapun saran dari hasil penelitian ini, diharapkan Kepada Rumah Peduli Nurul Fikri yang mana lembaga ini berpotensi menjadi lembaga yang berbasis nasional maka dari itu agar lembaga amil zakat Rumah Peduli Nurul Fikri dapat menyelesai izin dari BAZNAS pusat serta dalam pengelolaannya dapat meningkat seperti pemodalan wirausaha, cangkupan lembaga dapat mencapai pelosok desa, dan sosialisasi kepada masyarakat agar lebih sadar akan zakat. Bagi masyarakat hendaknya melakukan pengawasan atau kontrol sosial terhadap lembaga amil zakat, agar tidak terjadi penyalahgunaan dan penyimpangan pengelolaan zakat yang rawan sosial. Bagi instansi atau lembaga terkait pengelolaan zakat hendaknya melakukan upaya kerjasama melalui terintegrasinya pengelolaan zakat, baik data, dana, dan manajemen zakat yang akuntabel dan transparan sebagai sumber ekonomi umat yang dapat memberikan kemaslahatan yang seluasluasnya. 


\section{DAFTAR PUSTAKA}

Abduh, Sjuhada, dkk, Regulasi Zakat dan Kesejahteraan Sosial : Studi Legislasi dan Implementasi Perda Daerah, Jakarta: Badan Litbang dan Diklat Departemen Agama, 2009

Administrator, 2015, http:/www.rpnf.org/profil-rpnf/ Diakses pada tanggal 27 April 2015 Pukul 18.53 WIB.

Administrator, www.kemendagri.go.id, Undang-undang Republik Indonesia Nomor 23 Tahun 2011 Tentang Pengelolaan Zakat, diakses pada tanggal 11 April 2016.

Admistrator,http://ilmuhukumuin-suka.blogspot.co.id/2015/11/teori-teori-penegakanhukum-kesadaran.html, diakses pada tanggal 1 november 2016.

Al Albani, Muhammad Nashirudin, Shahih Sunan Nasa'i Jilid 2, (terjemah fathurahman dan Zuhdi), c. I, Jakarta: Pustaka Azzam, 2006.

Al Asqalani, Ibnu Hajar, Fathul Baari Penjelasan Kitab Shahih AlBukhari Buku 8, (terjemah Amiruddin),c. II, Jakarta: Pustaka Azzam, 2007.

Ali, Zainuddin, Metode Penelitian Hukum, Jakarta: Sinar Grafika, 2011.

Araujo, Lucio Borromeo de, Penerapan prinsip transparansi, akuntabilitas dan prtisipasi masyarakat dalam local development program di timorleste, http://luckyarezo.blogspot.co.id/2013/05/prinsip-transparansi-akuntabilitasdan.html, diakses pada tangal 9 april 2016.

Asnaini, Zakat Produktif Dalam Perpektif Hukum Islam, Yogyakarta: Pustaka Pelajar, 2008.

Az-zuhaili, Wahbah, Fiqih islam wa Adillatuhu jilid 3, Jakarta: Gema Insani, 2011.

Bungin, Burhan, Penelitian Kualitatif: Komunikasi, Ekonomi, Kebijakan Publik,dan Ilmu Sosial Lainnya, Jakarta: Kencana, 2008.

Departemen Agama RI, Al-Qur'an dan terjemahannya, Depok, Cahaya Qur'an, 2008.

Departemen RI, Manajemen Pengeloaan Zakat, Jakarta: 2009.

Ghoni, Djunaidi dan Fauzan Al-Mansur, Metodologi Penelitian Kualitatif, Jogjakarta: ArRuzz Media, 2012.

El-Madani, Fiqh Zakat Lengkap: Segala Hal Tentang Kewajiban Zakat dan Cara Membaginya, Yogyakarta: DIVA Press, 2013.

Gie, The Liang, dkk, Ensiklopedia Administrasi, Jakarta: CV Haji Masagung, 1989.

Hafidhuddin, Didin, Zakat Dalam Perekonomian Modern, Jakarta: Gema Insani Press, 2002. 
Hidayat, Ahmad, Transparansi Penyelenggaraan Pelayanan Publik Di Indonesia, http://kebijakan-publik.blogspot.co.id/2011/03/transparansi-penyelenggaraanpelayanan.html, diakses pada tanggal 15 juni 2016.

Karim, Helmi, Fiqih Muamalah, c. I, Jakarta: PT. Raja Grafindo Persada, 1993.

Kartoredjo, H.S, Kamus Baru Kontemorer, Bandung: PT Remaja Rosdakarya, 2014.

Marzuki, Peter Mahmud, Penelitian Hukum, Jakarta: Kencana, 2011.

Muhammad, Zakat Profesi: Wacana Pemikiran dalam Fiqh Kontemporer, Jakarta: Salemba Diniyah, 2002.

Muhammad dan Abubakar, Manajemen Organisasi Zakat, Malang: Madani (kelompok penerbit Instrans), 2011.

Moleong, Lexy J., Metode Penelitian Kualitatif, Bandung: Remaja Rosdakarya, 2004.

Nurwairah, Nahed, Permberdayaan Ekonomi Umat Melalui Wakaf, Sekolah Tinggi Agama Islam Palangka Raya: Jurnal Kajian Islam, volume 1 nomor 1: 2009.

Prastowo, Andi, Menguasai Teknik-teknik Koleksi Data Penelitian Kualitatif, Yogyakarta: DIVA Press, 2010.

Rahmaniar, Menggali Potensi Umat Melalui Zakat (Studi Terhadap Pelaksanan Zakat Di Kota Palangka Raya), Sekolah Tinggi Agama islam Palangka Raya, Jurnal Studi Agama dan Masyarakat, Volume 5 nomor 1, 2008.

Rizal, Muhammad, Akuntabilitas: Dalam Presfektif Islam, http://www.larispa.or.id/berita/127-akuntabilitas-dalam-presfektif-islam-.html, ， di akses pada tanggal 4 April 2016.

Saleh, amin Nur, http://www.nuraminsaleh.com/2016/02/teori-kesadaran-hukum-danketaatan-hukum.html, diakses pada tanggal November 2016.

Salman, Otje dan Anton F. Susanto, Teori Hukum Mengingat, Mengumpulkan dan Membuka Kembali, Bandung : PT Refika Aditama, 2004.

Soekanto, Soerjono, Pengantar Penelitian Hukum, Jakarta: Universitas Indonesia (UIPress), 1986.

Soemitro, Rony Hanitijo, Metodologi Penelitian Hukum, Jakarta: Ghalia Indonesia, 1985, cet. II 
Sucipto, Agus, “Membangun Transparansi dan Akuntabilitas Lembaga Pengelola Zakat”, http://bazkabgarut.blogspot.co.id/2011/04/membangun transparansi-dan.html, diakses pada tanggal 1 April 2016 pukul 16:00 WIB.

Subagyo, Joko, Metode Penelitian dalam Teori dan Praktek, Jakarta: PT. Rineka Cipta, 1997.

Sugiyono, Metode Penelitian Kuantitatif, Kualitatif dan R\&D, Bandung: Alfabeta, 2013.

Sukti, Surya, Hukum Zakat dan Wakaf Di Indonesia, Yogyakarta: Kanwa Publisher, 2013.

Sunggono, Bambang, Metologi Penelitian Hukum, Jakarta: Rajawali Pers, 2011.

Tanzen, Ahmad, Metodologi Penelitian Praktis, Yogyakarta, Teras, 2011.

Tim penyusun kamus pusat bahasa, Kamus Besar Bahasa Indonesia, Jakarta: Balai Pustaka, 2005.

Utsman, Sabian, Dasar-Dasar Sosiologi Hukum, Yogyakarta: Pustaka Pelajar, 2013.

Qardawi, Yusuf, Hukum Zakat, Jakarta: Pustaka Litera Antarnusa, 2007. 